Research article

\title{
Farmers' decisions to adapt to flash floods and landslides in the Northern Mountainous Regions of Vietnam
}

\author{
Nga Thanh Thi Pham ${ }^{\mathrm{a}, \mathrm{b}, *}$, Duy Nong ${ }^{\mathrm{c}}$, Matthias Garschagen ${ }^{\mathrm{d}}$ \\ ${ }^{\text {a }}$ United Nations University, Institute for Environment and Human Security, Germany \\ ${ }^{\mathrm{b}}$ Thai Nguyen University of Agriculture and Forestry, Viet Nam \\ ${ }^{\mathrm{c}}$ University of Bonn, Institute for Food and Resource Economics/Center for Development Research, Germany \\ ${ }^{\mathrm{d}}$ Ludwig-Maximilians-Universitat München (LMU), Department of Geography, Germany
}

\section{A R T I C L E I N F O}

\section{Keywords:}

Adaptation

Flash floods and landslides

Yen Bai province

Vietnam

Livelihood strategy

Multivariate probit model

\begin{abstract}
A B S T R A C T
Understanding household's decision making in agricultural production to natural hazards is significant for policymakers and extension organizations in supporting farmers to optimize adaptive strategies, there are, however, still limited empirical researches that emphasize the determinants affecting the choice of measures in the process of adaptation. This paper explores the decision-making process of rural households in adapting to flash floods and landslides (FF\&LS) by conducting a household survey on 405 purposively selected households in Yen Bai province, one of the poorest mountainous regions in Vietnam. Based on the multi-portfolio framework, the study assumes that farmers have multiple choice of adaptation strategies simultaneously and these adaptation measures are correlative. Multivariate Probit models were used to figure out the household decision making process in adapting to FF\&LS. Survey results showed that changing cropping patterns, crop variegation, diversifying types of crop varieties, as well as managing and implementing crop protection (soil and plant) are the primary adaptation measures applied by local farmers. Furthermore, lack of money, inadequate support from local government, shortage of machinery and technical equipment, as well as insufficient knowledge about FF\&LS were listed as major constraints in the study area. The MVP analysis indicated that all farmers' perception, socio-economic, farming features, and institutional conditions strongly influence the farmers' adaptation decisions regarding FF\&LS. Future policies may therefore need to consider these major contributing factors with appropriate interventions to facilitate suitable adaptations for local farmers.
\end{abstract}

\section{Introduction}

People's livelihoods in developing countries are often profoundly affected by natural hazards and extreme weather variability. However, they often recover slowly following hazard events because of a low adaptive capacity resulting from low income and undeveloped infrastructure. Enhancing farmers' adaptive capacity to natural hazards in agriculture in order to ensure food security is increasingly attracting the attention of scholars. Among different types of natural disasters, flash floods and landslides (FF\&LS) are considered to be the most frequent destructive hazards resulting in high mortality and significant economic losses in both agriculture and urban infrastructure (Salvati et al., 2018). They are also typical events in mountainous areas (Jonkman, 2005). In this regard, adaptation measures are considered one of the most appropriate approaches to reducing rural households' vulnerability and strengthening their livelihoods in face of the impacts of FF\&LS. The IPCC (2001), for example, indicated that the policy decisions on adaption play a crucial role in reducing vulnerability to climate change by improving the self-abilities of rural communities to adjust to climate change, to reduce potential damages, as well as to deal with adverse consequences.

There have also been various multidisciplinary studies carried out to examine the implications of farmers' adaptations to climate variability (Le Dang et al., 2014; Trinh et al., 2018). Adger and Vincent (2005), Below et al. (2012) and Smit and Wandel (2006), for example, found that to clarify the problematic sources of the vulnerability of individuals and to develop suitable adaptation plans, it is necessarily required to improve understanding and approaches of the adaptation processes of farmers. The IPCC (2001) also defined adaptation as changes in natural and human systems to react to realistic and anticipated climatic stimuli or their consequences, which would eventually limit damage or take

\footnotetext{
* Corresponding author. United Nations University, Institute for Environment and Human Security, Germany.

E-mail address: nga.pham@ehs.unu.edu (N.T.T. Pham).
} 
advantage of beneficial opportunities. In addition, adaptation can be classified as either planned adaptation or as autonomous adaptation. In the agricultural sector, the most common adaptation measures to climate varieties are the use of water or drought-tolerant crop varieties and livestock breeds, modern irrigation systems, crop variegation, integrated farming systems, as well as adjusting cropping calendars (Bradshaw et al., 2004; Deressa et al., 2009; Kurukulasuriya and Mendelsohn, 2006; Nhemachena and Hassan, 2008).

In this context, there are several studies that have been conducted which examine the impact of natural hazards or climate changes, such as droughts, floods and salinity intrusion, on the livelihood of rural households in Vietnam (Kam et al., 2012; McElwee et al., 2010; McKinley et al., 2016; Pham, 2011; UN-VietNam, 2014). These studies used either qualitative or quantitative methods to identify the critical drivers of farmers' responses to climate change. For example, running a binary logit model and multivariate probit model to examine the determinants of farmers' adaptive practice to climate change in agricultural production in the Central region of Vietnam, Trinh et al. (2018) pointed out that attendance in climate change training courses and farm size were among the most significant factors in explaining the farmers' adaptation behavior to changes of climate. However, this study has not yet considered several factors that would influence adaptation, such as farmers' perceptions of climate change and also the socio-economic and farming features (ethnicity, households' wealthy, land ownership, etc.). There are limited knowledge and understanding on how farmers give their priorities and their willingness/propensity in adaptation process to natural disasters. In addition, no empirical research is available that emphasizes the determinants affecting the choice of measures in the process of adaptation to FF\&LS in the mountainous context. Also, there is growing awareness of the need for field-based studies to accurately comprehend the adaptation responses to changes in climate at the local level in order to provide useful information for policy making and strengthening households' adaptation.

Against this background, our primary objective is to identify the main factors that influence the decisions of rural farmers in terms of adaptation to natural disasters, particularly FF\&LS. We select our case study in several communes in the remotely mountainous areas in the Northern Mountainous Regions in Vietnam, as these areas usually experience major FF\&LS annually. It is noted that FF\&LS are two events that usually take place simultaneously in this area. There is no perception by local people that these two events are separated. Therefore, when referring to the adaptation to either FF\&LS, people in the study area are always aware that their adaptation measures are for both FF\&LS. In other words, these two disasters can be considered to be a single event in the study area. Our hypotheses are that farmers' adaptive behavior in the region might be determined by their cognition of FF\&LS, socio-economic characteristics, farming features, and institutional conditions. We consequently aim at modeling the farmers' adaptation process by using a Multivariate Probit model. We also assume that farmers have multiple portfolios of adaptation strategies at the same time and these adaptation measures are correlative.

This study is not only important academically but also contains significantly practical implications, as studies of the adaptation strategies of rural farmers subject to FF\&LS are scarce, particularly for highly remote mountainous areas. More importantly, the Vietnamese government specifies that study area is an extremely poor region. Most people in the province belong to minority ethnic groups with low incomes, poor education, a lack of clothes, food, clean water and healthcare services, and undeveloped infrastructure. They also mainly rely on farming and forestry for food and livelihoods, which are highly vulnerable to natural hazards. Hence, the findings of this study provide sound references for the governments in Vietnam to understand local households' difficulties and behaviors in order to develop appropriate policies to help them recover quickly and sustainably from future natural hazards. In addition, the method and findings in this study are also appropriate references for other studies or government bodies facing similar economic, social and geographical contexts.

The paper is structured as follows: Section. 2 presents how data was collected and the empirical model used. The analyzed results as well as comprehensive discussion are presented in Section. 3 whilst the conclusions and policy implications are discussed in Section. 4.

\section{Materials and methods}

\subsection{Study zone and household survey}

Vietnam with its natural conditions and location is one of the countries most frequently and strongly influenced by various kinds of natural hazards, such as flash floods, tornadoes, landslides, tropical storms, and drought (IPCC, 2001; Marconi et al., 2011; World Bank, 2011). Average yearly precipitation in most parts of Vietnam ranges from $1400 \mathrm{~mm}$ to $2400 \mathrm{~mm}$. The distribution of rainfall, however, is uneven throughout the year and across regions, with roughly $80-90 \%$ of the precipitation concentrated in the rainy season, frequently leading of FF\&LS (Chaudhry and Ruysschaert, 2008). According to MONRE (2009), over the past 50 years, the average annual temperature has increased by 0.5 Celsius degree; annual precipitation has decreased in the North and increased in the South; and the sea level has risen about $20 \mathrm{~cm}$. Moreover, it is expected that by the end of the 21st Century, the average temperature in Vietnam would increase by 2.3 Celsius degrees; total annual rainfall and precipitation in the rainy season (May-October) would increase whereas dry season's rainfall (November-April) would decrease; and the sea level may rise about $75 \mathrm{~cm}$ compared to the period 1980-99.

Among natural disasters, FF\&LS have been particularly threatening to the life and productivity of people who live in remote rural areas, especially in the Northern Mountainous Regions where natural resources are significant sources of livelihood for most people. It is estimated that in ten years (from 2006 to 2016), there were a massive number of FF\&LS events happened in the mountainous regions of Vietnam (MONRE, 2017), which resulted in crop losses and destruction of housing and property. In addition, strong FF\&LS, with their extremely destructive characteristics, have trapped many rural households in a cycle of poverty (Marconi et al., 2011). In comparison with other areas in the Northern Mountainous Regions, Yen Bai province, which experienced an exceptionally huge number of deaths and injuries, was one of the most devastated areas. In addition, the affected areas in this province often become unreachable for weeks to months because of damaged roads. For example, it was reported by the People's Committee of Yen Bai in 2006that economic losses due to natural disasters were estimated to be between 10 and 50 billion VND per year, equivalent to $\$ 0.43-\$ 2.2$ million. In 2005, the province experienced five noticeable FF\&LS events which caused the deaths of 50 people. Also, the volume of soil eroded was estimated at about $75,000 \mathrm{~m}^{3}$, while 2607 ha of seasonal paddy and vegetables fields were flooded, most of which were destroyed (1200 ha and 1055 ha respectively). Recently in 2017, there were three consecutive events of FF\&LS in Yen Bai province that caused 16 deaths, 16 injuries, and washed away 50 houses (for more information, see Table A1 in Appendix).

The Vietnamese government consequently considered it a priority to resolve the issues in the region by implementing various policies and supportive programs in order to reduce poverty and achieve sustainable development. For example, the government set up natural disaster prevention and control committees at different provincial, district and communal levels. In addition, the government also provides in-kind and financial supports to households that suffered severely from natural hazards in order to recover from adverse impacts. For instance, Yen Bai province provided 10 million $\mathrm{VND} /$ person (or $\$ 430 /$ person) for households who lost family members, and 25 million VND (or \$1090) and $15 \mathrm{~kg}$ of rice/person/month for a two-month period for families whose houses were swept away or completely collapsed.

The research took place in Van Yen district, Yen Bai province, one of 
the poorest provinces in the Northern Mountainous Regions of Vietnam (World Bank, 2012). Yen Bai's per capita GDP in 2017 was estimated at $\$ 1306.08$ compared to the national average of $\$ 2389$ (GSO, 2017). The district covers $1391.54 \mathrm{~km}^{2}$ and comprises of three economic regions: the rice intensification (13 communes), fruit crop (6 communes) and cinnamon areas ( 8 communes). Among the 26 communes and one town in the district, the study area was made up of three purposively selected communes that are An Binh, An Thinh, and Dai Son (see Fig. 1). The selection of these communes was based on preliminary interviews with key informants, such as officials from the Departments of Irrigation and Flood Control, the Agricultural Department and the Statistical Department as well as local leaders in these communes. Each commune is characterized by a typical crop, for instance, in An Binh this is cassava production whereas in An Thinh and Dai Son it is rice and cinnamon respectively. Primary data were collected by conducting a household survey in two stages (see Fig. 2). The first stage was implemented from September to November 2015 and the second stage from February to April 2016. During the first stage, in-depth interviews and focus group discussions were carried out in order to capture the research context. At the same time, a pre-test of the questionnaire was also conducted with five households in each commune. After the pre-survey had been carried out, the questionnaire was then revised and a well-structured questionnaire was prepared for the formal household survey. The questionnaire was prepared in English and translated into Vietnamese later because the language used in the survey was Vietnamese.

In the second stage, the survey team included three experienced interviewers based at Thai Nguyen University, Vietnam. Initially three days were spent explaining the primary purpose and objectives of the study. The respondents were chosen based on the impact level of FF\&LS on their livelihoods and production activities, which were reported by local officers. Furthermore, only the responses of the household head or main laborer of the household were recorded since they are not only decision makers but also often have better memory related to issues of production activities in their households. The samples included 154 households in An Binh, 105 households in An Thinh and 146 households in Dai Son making a total sample size of 405 . The data was collected under nine broad headings, including: (1) household profile: age, education level, ethnicity, household condition, (2) land use: farm size, land ownership, (3) crop production: planted crops, crop varieties, using of plant protection products, fertilizers and pesticides, crop yields, crop prices, (4) irrigation: source of irrigation water, sufficiency of irrigation sources, irrigation fee, (5) livestock and aquaculture: types of livestock, aquaculture, number of livestock currently owned, (6) market, extension, assets/savings/loans/income: distance to market, difficulties in agricultural productions, extension services, household durable goods, credit availability, sources of income, (7) the perception of climate variability: farmers' perception of rainfall, drought, temperature, flash flood, landslide, (8) adaptation decisions: impacts of FF\&LS to agricultural production, adaptation responses, difficulties in adaptation, and (9) social capital: sources of assistance during and after FF\&LS. Particularly, the dependent variable was collected by asking the respondents whether they have noticed any changes of FF\&LS, what have been the impacts of FF\&LS on their agricultural production, and what practices they had taken to adapt to FF\&LS. It took approximately $1-1.5 \mathrm{~h}$ to interview each respondent.

\subsection{Theoretical background}

In recent years, the discourse of adaptation has attracted attention of researcher and experts in climate change since changes in climate are considered one of the crucial elements that threaten food security and livelihoods. To date, there are a number of different bodies on the adaptation assessment of climate change. Fundamentally, the technology adoption framework and the utility maximization framework are often applied to analyze adoption decisions (Norris and Batie, 1987) and to model farmers' adaptation to climate change (Waibel et al., 2018). These approaches indicate that an individual will adopt a technology if he/she perceives that the adoption will bring him/her higher utility or net profit. Theoretically, a combination of portfolios is preferable since it results in higher benefit. However, as pointed out by Dhakal (2016), there is always a link between one decision and others in the individual decision-making process in the case of multiple options. Therefore, it will be meaningful to consider the multi-portfolio decision approach in explaining the joint decision problem. In this study, we follow this approach to figure out the determinants affecting decisions of households in adapting to FF\&LS.

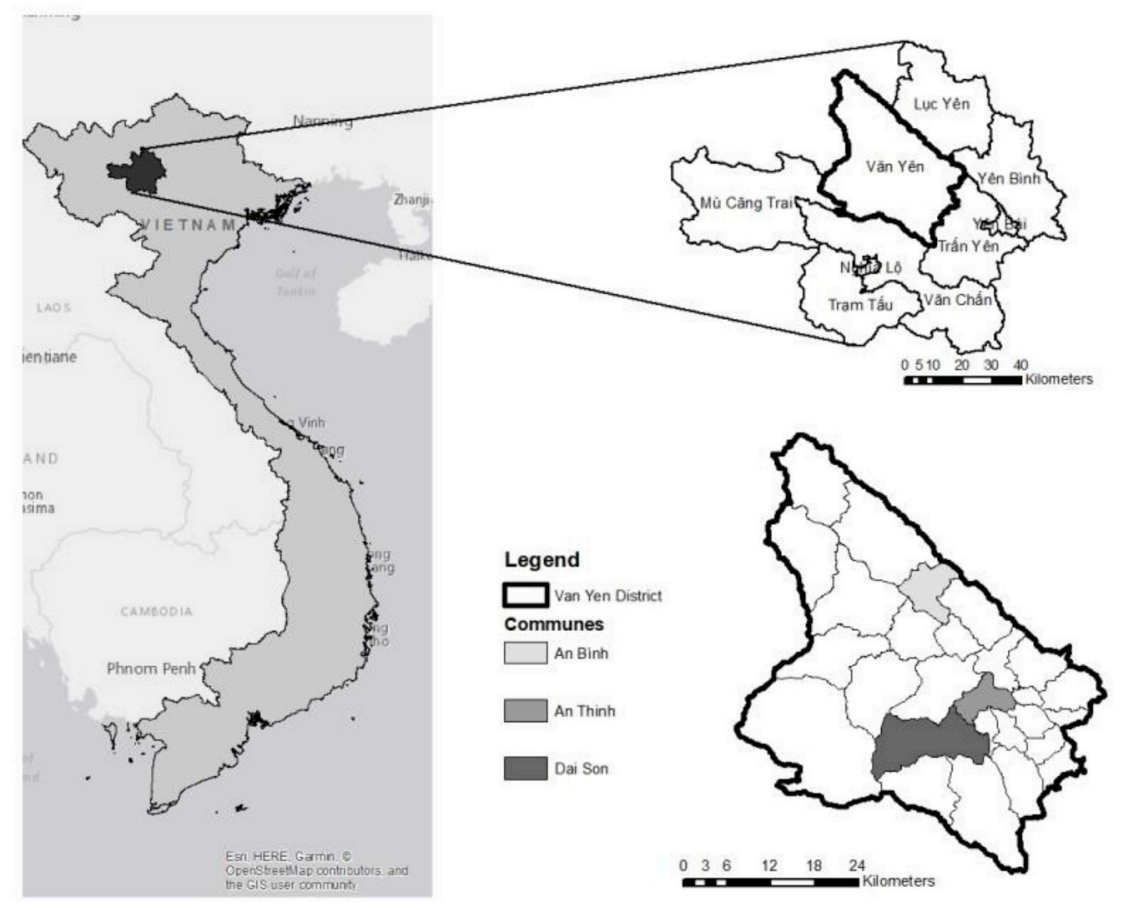

Fig. 1. Map of the study areas. 


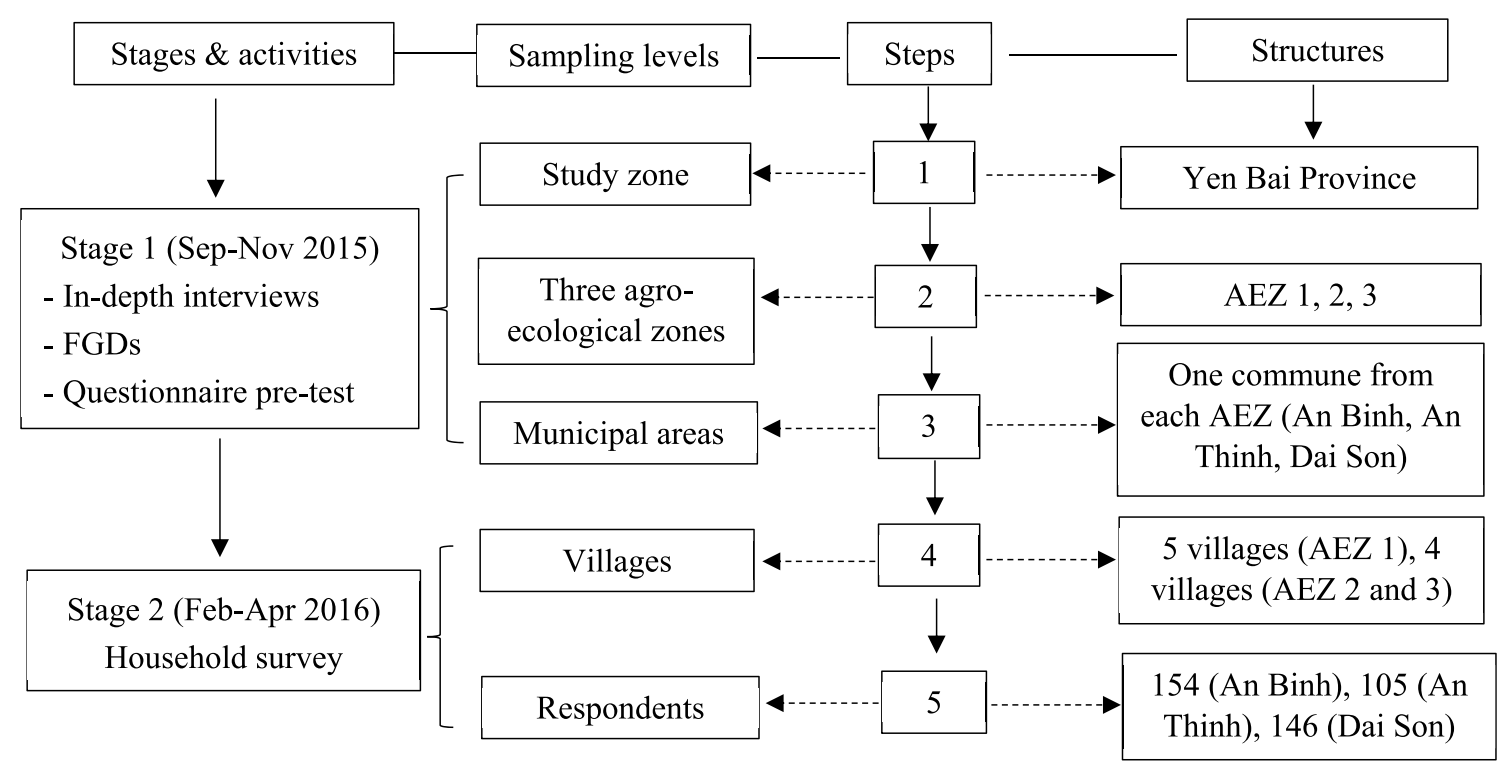

Fig. 2. Sampling procedure in the study areas. Note: FGD refers to Focus Group Discussion; AEZ stands for agro-ecological zones.

The socio-economic, demographic, and structural factors have been preoccupated of many researchers in understanding the determinants of household adaptation to new technologies (e.g., irrigation technology) (Koundouri et al., 2006). Among these factors, risk has been recognized as a key element affecting the adoption level of individuals (Jensen, 1982; Just and Zilberman, 1983). In addition, based on an assumption of farmers' risk aversion, the results by Koundouri et al. (2006) and Saha et al. (1994) indicated that risk and incomplete information play a significant role in farmers' decisions. It is the fact that risks in practice and the availability of information sources have a direct impact on perceptions of individuals in making adaptive decisions. It is also important to point out that adoption of new technologies is frequently driven by economic profits whereas adaptations to climate change are considered as responses to reduce risks and to minimize potential losses. Both of these adoptions are directly influenced by perception of actual or expected changes. Hence, it is indispensable to link perception of farmers in an adoption model in the context of climate change or natural hazards (Grothmann and Patt, 2005; David Maddison, 2006). In addition, adoption decisions of farmers are assumed to be influenced by land availability (farm size and tenure arrangements), access to credit, and other constraints, such as risk/uncertainty (weather variations), human capital, supply constraints (the availability of complementary inputs) (Feder et al., 1985). In doing so, in this study we aim at modeling the farmers' adaptations by considering farmers' perception, socio-economic characteristics, farming features, and institutional conditions as exogenous variables in explaining how farmers adapt or not adapt to natural disasters (i.e., flash floods and landslides).

Most of the households in the research areas have adopted more than one strategy as responses to FF\&LS. In fact, however, not all strategies followed by farmers relate directly to FF\&LS. There may be some other push or pull factors unrelated to FL\&LS which may have driven the farmers to adopt to practices. For example, changing cropping pattern from cassava to cinnamon or acacia could be affected by market factors (increasing price of cinnamon) and by imitation process (the farmers imitate their neighbor in selecting adaptation measures). In other words, this adaptation might be driven by economic profit rather than the impacts of FF\&LS. However, these factors might not be significant in the study areas, as the prices of agricultural commodities do not change considerably so that farmers would change their cropping pattern. In addition, cultivating cassava by households in the study areas in the past is one of the key causes leading to increasing risks of landslides in the region. Also, the research areas are severely prone to FF\&LS. Therefore, this study assumes that farmers' adaptation by not only changing cropping pattern but also other practices are driven by FF\&LS.

\subsection{Empirical model}

Analytical approaches are often used to analyze adaptation decisions in general and decision-making processes for adaptation to climate change in particular. Of these, the Multinomial Logit (MNL) or the Multinomial Probit (MNP) models are broadly used. In these models, the estimation of the explanatory variables effects on a multi-choice dependent variable is carried out, regardless the need of knowing the order of response categories. The application of both MNL and MNP to explore determinants of farmer adaptation choices due to unfavorable changes in climate has been carried out by many scholars (for example, see Deressa, 2009; Gbetibouo, 2009; Kurukulasuriya and Mendelsohn, 2006; Nhemachena and Hassan, 2008). The main advantages of the MNL are: (1) the simplicity in computation of choice probabilities (Tse, 2006), and (2) the possibility of analyzing decisions across multiple groups, enabling the determination of choice probabilities for different categories (Wooldridge, 2008). Both the MNL and MNP models represent the potential outcomes that indicate adaptation decisions as one joint decision. This means that the issues in explaining how explanatory variables affect the original separated adaptation choices are likely to be found in multinomial replications of a multivariate choice system (Nhemachena and Hassan, 2008). As farmers' adaptation choices are either substitutive or supplementary of one another, the goal of modeling adaptation strategies to FF\&LS in the study is to isolate the effects of exogenous variables on each of the adaptation measures. In such situations, a Seemingly Unrelated Regression (SUR) model is introduced. This model assumes that farmers' responses to FF\&LS includes all different adaptation choices. Thus, there might be a correlation between the decision to undertake one given strategy and the adaptation of another option.

Accordingly, in order to overcome the aforementioned issues and to determine the factors influencing farmers' strategies of particular adaptation measures, the Multivariate Probit regression model (MVP) is employed. The MVP model examines simultaneously the influence of the set of independent variables on each of the different adaptation choices whereas allowing the error terms of unobserved factors to be correlated without constraints (Golob and Regan, 2002; Lin et al., 2005). Such a method has been using widely. For example, Nhemachena and Hassan (2008) employed the MVP model to identify the adaptation schemes to 
climate variation in farm-level households in Southern Africa. Similar studies were also conducted in the rural Mid-Hills of Nepal (Piya et al., 2013), in Northern Ethiopia (Feleke et al., 2016), and in Northern Benin (Yegbemey et al., 2013). In addition, Piya et al. (2013) highlighted that the MVP model presents one major advantage compared to the MNL model by relaxing the assumption of Independence of the Irrelevant Alternatives (IIA), which is often unrealistic in numerous cases. The MVP model used in this research is characterized by a set of $\mathrm{n}$ binary dependent variables $\mathbf{A}_{\mathbf{i}}$ and contained a set of household characteristics, as shown in (1):

$\begin{array}{llll}\mathbf{A}_{\mathbf{i}} & \boldsymbol{\beta}_{0} & \sum_{\mathbf{j}} \boldsymbol{\delta}_{\mathbf{j}} \mathbf{z}_{\mathbf{i j}} \quad \mathbf{k}_{\mathbf{i}}\end{array}$

where:

$\boldsymbol{\beta}_{0}, \mathbf{k}_{\mathbf{i}}$ are the intercept and error terms, respectively; $\boldsymbol{\delta}_{\mathbf{j}}$ are the estimated parameters; $\mathbf{z}_{\mathbf{i j}}$ stands for $\mathbf{j}$ farmers' perceptions of FF\&LS, socio-economic characteristics, farm characteristics, and institutional conditions.

In this research, the adaptation behavior of farmers to FF\&LS was modelled by using discrete dependent variables with multiple choices. The farmers were asked to indicate whether they had adapted by means of the following methods:

Adjusting planting time

Changing cropping pattern

Use of different crop varieties

Farming diversification

Changing in land use purposes

Selling properties

Receiving external supports (the local government/friends/relatives)

Borrowing financial resources

Migration

Income from off-farm jobs

Using more plant protection products, i.e. chemicals and fertilizers

Adoption of mulching for soil moisture conservation

Once examining the frequency of aforementioned adaptation measures based on the survey reports, the adaptation strategies are finally categorized into five different groups: changes in cropping pattern, use of different crop varieties, crop variegation, crop management and protection (including soil and plant), and others.

In fact, this research only considers the case of whether a household takes adaptation strategies or not, without considering the intensity/ degree of the applications. Since the farmers are only able to provide their opinion about whether or not they implemented these measures without knowing how much or to what degrees they applied these measures. Hence, it is more appropriate to use the binary scale for variables.

Farmers in the research area often choose multiple strategies as a way to adapt to FF\&LS rather than relying on a single practice. Therefore, in this study, the MVP model includes five simultaneous models. Each adaptation decision of farmers is a discrete choice form, in which 1 denotes farmers who adopt the practice and 0 if otherwise. Hence, for each adaptation decision, the MVP is specified as follow:

$$
\mathbf{A}_{\mathbf{n i}} \quad\left\{\begin{array}{lll}
1 \text { if } \mathbf{A}_{\mathbf{n i}} & \boldsymbol{\beta}_{\mathbf{n}} \sum_{\substack{\mathbf{j} \\
0}} \boldsymbol{\delta}_{\mathbf{n j}} \mathbf{z}_{\mathbf{i j}} \quad \mathbf{k}_{\mathbf{n i}}>0 \\
0 \text { otherwise } &
\end{array}\right.
$$

where:

$\mathbf{n}$ is the number of observations ( $\mathrm{n} \quad 405)$;

$i$ is the number of adaptation options ( $i$ );

$\boldsymbol{\beta}$ stands for the constant term;

$\boldsymbol{\delta}$ is the estimated parameters; and

$\mathbf{k}_{\mathbf{n}}$ are the error terms having multivariate normal distribution.
The MVP model uses the method of Simulated Maximum Likelihood (SML) to estimate the contribution of explanatory variables (household attributes) to farmers' adaptation decisions.

\subsection{Selection of explanatory variables and tested hypotheses}

The farmers' decisions to undertake particular adaptation strategies is influenced by numerous exogenous elements. Based on the review of relevant literature on adaptation studies, theoretical behavioral hypotheses, observations during the fieldwork, and data availability, a set of exogenous variables in the model were identified. In this study, the foundational assumption was that adaptation can be influenced by (1) farmers' perceptions of FF\&LS, (2) socio-economic characteristics (i.e., age of the leader, ethnicity, literacy, household condition (poor or nonpoor household), farm and non-farm income, market availability), (3) farm characteristics (land ownership, farm size), and (4) institutional conditions (irrigation system access, extension service connection, and credit availability). The considered explanatory variables, as well as their expected influences are illustrated in Table 1.

The perception of farmers is considered an essential precondition to adapt to natural hazards (D Maddison, 2006) as people will have higher chances of undertaking adaptation options if they are aware of changes in climatic conditions. The study, therefore, assumes that the probability of adopting adaptation strategies will be higher if farmers perceive and are aware of FF\&LS.

(2) Socio-economic characteristics.

The age of the leader is somewhat linked with the level of farming experience. Studies by Anim (1999), Bekele and Drake (2003), Thacher et al. (1996), and Zhang and Flick (2001) revealed that age does not influence farmers' decisions to take part in reforestation investment, or soil and water management activities. On the other hand, it was found that age of the household head has a negatively significant relationship with the farmers' decisions to adapt (Anley et al., 2006; Burton et al., 1999; Dolisca et al., 2006; Featherstone and Goodwin,

Table 1

Descriptions of explanatory variables in the adaptation model.

(1) Farmers' perceptions of FF\&LS.

\begin{tabular}{|c|c|c|c|}
\hline Variables & Type & Modalities & $\begin{array}{l}\text { Expected } \\
\text { sign }\end{array}$ \\
\hline \multicolumn{4}{|l|}{ Farmers' perceptions } \\
\hline Perceptions of FF\&LS & $\mathrm{D}$ & $\begin{array}{l}0 \quad \text { No; } 1 \\
\text { Yes }\end{array}$ & \\
\hline \multicolumn{4}{|l|}{ Socio-economic characteristics } \\
\hline Age (years) & $\mathrm{C}$ & _- & \\
\hline $\begin{array}{l}\text { Level of education (degree) (1: Illiteracy; } \\
\text { 2: Primary school; 3: Secondary school; 4: } \\
\text { High school and higher) }\end{array}$ & $\mathrm{C}$ & - & \\
\hline Ethnicity & $\mathrm{D}$ & $\begin{array}{l}0 \quad \text { No; } 1 \\
\text { Yes }\end{array}$ & - \\
\hline Household condition (Poor household) & $\mathrm{D}$ & $\begin{array}{l}0 \quad \text { No; } 1 \\
\text { Yes }\end{array}$ & - \\
\hline Farm income (log) & $\mathrm{C}$ & - & \\
\hline Non-farm income (log) & $\mathrm{C}$ & - & \\
\hline Market availability $(\mathrm{km})$ & $\mathrm{C}$ & - & - \\
\hline \multicolumn{4}{|l|}{ Farm characteristics } \\
\hline Land ownership & $\mathrm{D}$ & $\begin{array}{l}0 \quad \text { No; } 1 \\
\text { Yes }\end{array}$ & \\
\hline Farm size (ha) & $\mathrm{C}$ & - & \\
\hline \multicolumn{4}{|l|}{ Institutional conditions } \\
\hline Irrigation & $\mathrm{D}$ & $\begin{array}{l}0 \quad \text { No; } 1 \\
\text { Yes }\end{array}$ & \\
\hline Extension service connection & $\mathrm{D}$ & $\begin{array}{l}0 \quad \text { No; } 1 \\
\text { Yes }\end{array}$ & \\
\hline Credit availability & $\mathrm{D}$ & $\begin{array}{l}0 \quad \text { No; } 1 \\
\text { Yes }\end{array}$ & \\
\hline
\end{tabular}

Note: D: Discontinuous variables; C: Continuous variables. 
1993; Gould et al., 1989; Lapar and Pandey, 1999). Bayard et al. (2007), however, indicated that age was significantly and positively related to the adaptation of conservation measures. The present study, therefore, expects that the age of the household head has both positive and negative effects on adaptation practices.

The literacy influences farmers' access to proper information and promotes the implementation of upgraded technologies in farming practices. According to Adesina and Baidu-Forson (1995), Daberkow and McBride (2003), and Deressa (2009), high levels of education among household heads increase the probability of taking up adaptation measures and adopting new technologies. Furthermore, farmers possessing better academic level are more likely to uptake adaptation choices to climate change (D Maddison, 2006). Hence, this study hypothesizes that educated farmers are more probably to adapt to FF\&LS. Ethnicity of the household head has an effect on adaptation. For instance, it is emphasized by CARE (2013) that Vietnam's ethnic minorities in the Northern mountainous areas are significantly poorer than Vietnam's ethnic majority (the 'Kinh' people). In addition, although there are significant differences in terms of socio-economic characteristics among the 53 ethnic minority groups in Vietnam, a Vietnamese person belonging to an ethnic minority is usually born into poorer conditions rather than a person born into a 'Kinh' family within the same region. Following this statement, ethnic minorities are expected to be less likely to invest in adaptation measures to FF\&LS since they are normally poorer than the 'Kinh' people, and often live in remote areas and villages where are less endowed with good infrastructure (Pham et al., 2010).

Household condition (poor or non-poor household) is another factor affecting adaptation. Based on income criteria, the Vietnamese government defines a poor rural household as one which only has an income equal to or below 700,000 VND (around \$30) per person per month. A benchmark of 900,000 VND (around \$39) per person per month applies to urban areas. In general, the livelihood resources and options of the poor to respond are typically narrower and more climate-sensitive than the non-poor (African Development Bank, 2003; Hallegatte et al., 2016). This means that higher-income households have a greater ability to carry out adaptation options to climate stimuli. Consequently, this study hypothesizes that wealthier households are more probably to adapt to FF\&LS.

Farm income and non-farm income indicate the diversity of income sources. In general, households with diversified income sources are less vulnerable and more likely to quickly recover from natural hazard-induced shocks than people that subsist on a single source of income. In addition, high income from either farm or non-farm activities is representative of a household's wealth. Shiferaw and Holden (2006) stated that higher-income households are in a better position to adopt new farming technologies. Hence, it is expected that higher income farmers have a higher probability of using adaptation measures to FF\&LS.

Market availability indicates how far farmers can reach places where people come to sell their homemade products and buy necessary commodities. Since markets can be considered to be places for information exchange among farmers, Maddison (2006) pointed out that proximity to markets is one of the significant factors of adaptation. Moreover, with favorable distances to the market, farmers have higher chances to trade products with others by selling their farming products, and buying merchandises, such as fertilizers, new crop varieties, and irrigation facilities as well as to sell their farming products. Thus, it is hypothesized that the less market availability, the less adaptable farmers are to FF\&LS.
(3) Farming characteristics. Land ownership is often represented by a certificate that proves the legal ownership rights of households to the land that they are using. With these rights, farmers can mortgage their land to banks, credit institutions or other farmers in order to borrow money so that they can have additional financial sources to use for production or purchasing new farming technology such as threshers, harvesters, winnowing machines, selective breeding, pesticides, chemical fertilizers, and insecticides. Accordingly, land ownership is assumed to be positively correlated with decision making processes of farmers to adapt to FF\&LS.

In the research areas, farm size is one of the criteria characterized for a households' wealth. Farm size has been suggested as not an essential factor behind motivating adaptation measures (Anim, 1999). However, it was highlighted that farmers with larger farms are more likely to construct embankments and improved cut-off drains (Anley et al., 2006; Okoye, 1998) while small farms are correlated with soil conservation investment decisions (Nyangena, 2008). Hence, this study assumes that farm size has either a positive or negative effect on undertaking adaptation to FF\&LS.

(4) Institutional conditions.

Access to irrigation systems plays a crucial role in agriculture to maintain productivity and production levels so that farmers can earn constant revenues and reduce the risk of food insecurity. An adequate irrigation system allows farmers to increase the number of crops harvested in a year. It is therefore expected that access to irrigation systems is positively related to the uptake of adaptation measures to FF\&LS.

It is well-known that extension services deliver a significant source of information on agricultural production practices and a changing climate. Evidence from various studies (e.g., Adesina and Baidu-Forson, 1995; Maddison, 2006; Nhemachena and Hassan, 2008) indicates that access to extension services increases the likelihood of adopting adaptation measures to climate change. Hence, contact with agricultural extension services is hypothesized to be positively correlated with adaptation choices to FF\&LS.

Increasing the possibilities of access to credits helps farmers to strengthen their farming practices in response to changing climatic conditions. Deressa (2009) showed that access to credit has a significant positive impact on the likelihood of choosing adaptation strategies. Hence, here it is expected that credit availability has positive influences to adaptation options to FF\&LS.

\section{Results and discussion}

\subsection{Farmers' characteristics}

Table 2 presents the characteristics of respondents in the research areas. It includes information in terms of farmers' perceptions towards FF\&LS, their socio-economic characteristics, farming features, and institutional conditions. The results indicated that nearly half of respondents realized the increasing trend of FF\&LS over the past 15 years. In addition, on average, the age of the household heads in the study area was 46.70 ( 10.83 ) years old with $65 \%$ belonging to ethnic minority communities such as Dao, Tay, and Hoa. The level of education, however, was low with $42 \%$ of household heads lacking even primary school education. The poor households occupied approximately $29 \%$ of the total samples. Most of the households in the study regions listed agriculture as the major income generating activity; hence, farm income contributed to the majority share of their total income. Moreover, the average distance to the nearest market was $3.73 \mathrm{~km}$.

In Vietnam, in order to prove the legal ownership of land, the landowner must have a land certificate called the Red Book. It was 
Table 2

The details of explanatory variables used in the adaptation model.

\begin{tabular}{|c|c|c|c|}
\hline Variables & Type & $\begin{array}{l}\text { Frequency/ } \\
\text { Mean }\end{array}$ & $\begin{array}{l}\text { Percentage/Standard } \\
\text { deviation }\end{array}$ \\
\hline $\begin{array}{l}\text { Perceive increasing flash } \\
\text { floods }\end{array}$ & $\mathrm{D}$ & 199 & 49.14 \\
\hline $\begin{array}{l}\text { Perceive increasing } \\
\text { landslides }\end{array}$ & $\mathrm{D}$ & 171 & 42.22 \\
\hline \multicolumn{4}{|l|}{ Socio-economic characteristics } \\
\hline Age (years) & $\mathrm{C}$ & 46.70 & 11.6 \\
\hline Level of education (degree) & $\mathrm{C}$ & 1.99 & 0.99 \\
\hline Ethnicity & $\mathrm{D}$ & 260 & 64.20 \\
\hline $\begin{array}{l}\text { Household condition (Poor } \\
\text { household) }\end{array}$ & $\mathrm{D}$ & 116 & 28.64 \\
\hline Farm income (million VND) & $\mathrm{C}$ & 55.99 & 80.55 \\
\hline $\begin{array}{l}\text { Non-farm income (million } \\
\text { VND) }\end{array}$ & $\mathrm{C}$ & 35.06 & 42.62 \\
\hline Market availability (km) & $\mathrm{C}$ & 3.73 & 2.68 \\
\hline \multicolumn{4}{|l|}{ Farm characteristics } \\
\hline Land ownership & $\mathrm{D}$ & 293 & 72.35 \\
\hline Farm size (ha) & $\mathrm{C}$ & 2.31 & 2.52 \\
\hline \multicolumn{4}{|l|}{ Institutional conditions } \\
\hline Access to irrigation & $\mathrm{D}$ & 261 & 64.44 \\
\hline $\begin{array}{l}\text { Extension service } \\
\text { connection }\end{array}$ & $\mathrm{D}$ & 98 & 24.20 \\
\hline Credit availability & $\mathrm{D}$ & 259 & 63.95 \\
\hline
\end{tabular}

Note: Frequency and Percentage in case of qualitative (dummy) variables; Mean and Standard deviation in case of quantitative (continuous) variables.

observed that $27.5 \%$ of the land in the surveyed area was without the Red Book. On average, the farm size was 2.31 ha, and the majority of these lands can access irrigation systems (64\%). On the contrary, only about one-fourth of farmers were in extension service connection while a relatively higher proportion of respondents reported credit availability (64\%).

\subsection{Farmers' adaptation strategies to FF\&LS and constraints}

\subsubsection{Farmers' responses to FF\&LS}

As aforementioned, FF\&LS usually happen at the same time in the study area and local people perceive that these two disasters are actually only one disaster. We consequently assume that adaptation practices implemented by households are always for both FF\&LS together. In the research regions, various strategies were applied by farmers in order to adapt to and get rid of the negative impacts of FF\&LS. The strategies include two main categories: 1) internal farming activities, such as adjusting sowing/planting times, changing cropping and livestock pattern and varieties, diversifying farming, changing land use, selling land/livestock/asset, and 2) external supports, such as assistance from government/relatives or friends, and borrowing financial resources. The adaptation strategies are grouped into five classification depending on the frequency they are used in practices (see Table 3).

In the research area, the local farmers use changing cropping patterns as a common adaptation strategy (amounted for $37.04 \%$ of the total respondents). For instance, farmers plant acacia and cinnamon on the hills instead of growing cassava to avoid landslides since cassava cultivation was considered to be one of the main reasons resulting in land erosion, thereby increasing the risk of landslides. Another practical

Table 3

Household adaptation practices in the research regions.

\begin{tabular}{ll}
\hline Adaptation practices & $\begin{array}{l}\text { Proportion of households used } \\
(\%)\end{array}$ \\
\hline Changing cropping patterns & 37.04 \\
Crop variegation & 51.36 \\
Use of different crop varieties & 81.23 \\
Crop management and protection (soil and & 86.91 \\
$\quad$ plant) & \\
Other adaptations & 69.88 \\
\hline
\end{tabular}

advantage of this adaptation strategy is increases in household incomes. Diversifying crops was also another strategy adopted by over half of the respondents (51.36\%). In the past, farmers produced rice in two seasons annually; hence, land sometimes is free without planting any trees. Later, during the leisure time after harvesting rice, farmers started growing maize to prevent soil erosion caused by heavy rain. In hilly terrain, cassava was intercropped with cinnamon during the early stages of cinnamon growth. This method increases coverage and reduces water flow to limit soil erosion and leaching, thereby helping farmers keep soil fertility and improve economic value per the same area unit. In addition, another method that $81 \%$ of the respondents widely adopted was short duration and flood tolerant crop varieties. In order to encourage the use of tolerant varieties, local authorities also reduced their price. Furthermore, almost $87 \%$ had adopted soil management and plant protection strategies. This is because FF\&LS also cause soil degradation and outbreaks of crop pests; hence, to improve soil fertility and limit damages caused by pests, farmers used more protection means for plants like pesticides, fertilizers, as well as adopted mulching technique on their lands. Farmers who had fields adjacent to streams adopted many soil conservation activities, such as construction of embankments, weaving stone baskets and planting bamboo trees to prevent damage from landslides.

\subsubsection{Challenges for controlling adverse impacts of FF\&LS}

The terms of limits and barriers are mostly used interchangeably by researchers in the field of adaptation to climate change (Moser and Ekstrom, 2010). Barriers refer to the interfered conditions, factors or obstacles that weaken the efficiency of adaptation strategies. To overcome the barriers, both individual efforts and social exertion such as cognitive changes, creative management, changing of prioritization, institutions, use of land and resources, etc., should be taken into account. Several barriers to adaptation in agriculture have been reported, such as inadequate information on climate and climate impacts, lack of adaptive capacity, inefficiency extension, institutional inertia, cultural acceptability, and financial constraints (e.g., access to credit, inadequate fertile land, infrastructure, lack of functioning markets, and insurance systems) (IPCC, 2014). Limits, on the other hand, are the conditions or factors making climate change adaptation less effective and difficult to overcome (Adger et al., 2007). The present study, therefore, pinpoints significant barriers to adaptation processes comprising physical and ecological limits, technological limits, financial restrictions, informational and cognitive barriers, and social and cultural barriers.

According to the farmers, the barriers experienced in adapting to FF\&LS are: a lack of production means and family labor forces, a limitation of knowledge about FF\&LS, difficulties in accessing recent weather information, insufficient or limited support from local government, social and cultural barriers, and limited awareness.

It is noted that inadequate financial resources are claimed as a major constraint to farmers in implementing adaptation strategies $(73 \%$ of total respondents as shown in Table 4). Bryan et al. (2009) also stated that a lack of adequate credit facilities causing financial barriers was one of the most critical hindrances that obstructs the implementation of appropriate climate adaptation choices. People in the research area did not have adequate money to purchase farm inputs, such as hybrid seeds, fertilizers, pesticides, and farm implements. House repair and clearing rocks in the field or on the hills were also not carried out in time due to budget constraints. About $64 \%$ of the total interviewed households stated that they do not have machinery and equipment to support them in agricultural production, for example, tractors and ploughs. Therefore, they often had to hire these machines. As a result, in these three communes, there are numerous fallow fields and hills because people have no money or machinery to overcome the impacts of FF\&LS.

As indicated by Antwi-agyei et al. (2013), access to appropriate climatic information is a useful tool that can be used to improve the implementation of adaptation measures by households. Inappropriate climate information could be critical for food security (Antwi-agyei 
Table 4

Farmers' difficulties in coping with and preventing FF\&LS.

\begin{tabular}{|c|c|c|c|c|c|}
\hline & $\begin{array}{l}\text { A Binh } \\
\text { (1) }\end{array}$ & $\begin{array}{l}\text { A Thinh } \\
\text { (2) }\end{array}$ & $\begin{array}{l}\text { Dai Son } \\
\text { (3) }\end{array}$ & $\begin{array}{l}\text { Average } \\
\text { (4) }\end{array}$ & $\begin{array}{l}\text { P-value } \\
\text { (5) }\end{array}$ \\
\hline $\begin{array}{l}\text { Lack of weather } \\
\text { information }\end{array}$ & $40.91 \%$ & $36.19 \%$ & $34.25 \%$ & $37.28 \%$ & 0.473 \\
\hline Lack of money & $77.92 \%$ & $58.10 \%$ & $79.45 \%$ & $73.33 \%$ & 0.000 \\
\hline $\begin{array}{l}\text { Lack of local } \\
\text { government } \\
\text { supports }\end{array}$ & $40.26 \%$ & $48.57 \%$ & $40.41 \%$ & $42.47 \%$ & 0.339 \\
\hline $\begin{array}{l}\text { Social and cultural } \\
\text { barriers }\end{array}$ & $16.23 \%$ & $9.52 \%$ & $45.21 \%$ & $24.94 \%$ & 0.000 \\
\hline $\begin{array}{l}\text { Lack of knowledge } \\
\text { about FF\&LS }\end{array}$ & $47.40 \%$ & $46.67 \%$ & $58.90 \%$ & $51.36 \%$ & 0.074 \\
\hline $\begin{array}{l}\text { Lack of machinery } \\
\text { and technical } \\
\text { equipment }\end{array}$ & $53.90 \%$ & $46.67 \%$ & $86.99 \%$ & $63.95 \%$ & 0.000 \\
\hline $\begin{array}{l}\text { Shortage of labor in } \\
\text { family }\end{array}$ & $37.91 \%$ & $23.81 \%$ & $42.77 \%$ & $35.89 \%$ & 0.008 \\
\hline $\begin{array}{l}\text { Do not know what to } \\
\text { do }\end{array}$ & $16.23 \%$ & $28.57 \%$ & $13.70 \%$ & $18.52 \%$ & 0.007 \\
\hline
\end{tabular}

P-value calculated from Pearson's chi-squared test.

Source: Our field survey, 2016.

et al., 2013) and decreases successful implementation of adaptation technologies or limits adequate adaptation to climate change (Adger et al., 2009). The results from the household survey pointed out that a limitation of general knowledge about FF\&LS and inadequate weather information was perceived as barriers for adaptation in the three communes ( $52 \%$ and $37 \%$ of respondents, respectively).

Inadequate support from local government bodies was another constraint suggested by $43 \%$ of the respondents. Davies (1996) defined institution as the social links which connect stakeholders to reach various capital sources with the means of enforcing power could determine the sources of information in which they pass on the route to positive or negative adaptation. Institutions not only play an essential role in improving the capacity of local municipalities to cope with climate variability (Agrawal and Perrin, 2008), but also are a key to eliminating obstacles to climate adaptation (Biesbroek et al., 2013). To facilitate scientific applications in farming activities that include the implementation of innovative farming methods, extension officers are considered to be the connecting link between the scientific community and farmers. However, the results from field surveys indicated that extension activities in these communes were not efficient because of two main reasons. The first reason is that most of the extension officers are young and do not have much work experience. The other reason is that they do not have a high responsibility in their job (they did not go directly to farmers' homes to disseminate knowledge). Most interviewed households answered that there was no visit of extension staff to their home in the last year (in 2015). Besides, the local government also provided financial support for households who are vulnerable to landslides to move to safer places. However, each household received only around 15 million VND (around \$650) which was not enough to pay the total costs of moving. As a result, despite recognizing their dangerous situations some households remained put and imperiled their lives due to financial constraints.

Culture is an essential element to understanding the causes and meaning behind people's responses to climate change. Furthermore, different cultural groups will act differently to the severe impacts of climate change, even within the same geographical region (Adger et al., 2013). The survey results indicated that $61 \%$ of respondents are from minority ethnic groups, and $40 \%$ of them did not even go to school; social and cultural barriers are therefore considered to be one of their constraints in adopting adaptation strategies to deal with the adverse impacts of FF\&LS. About 36\% of interviewed households reported a shortage of labor in their family, and $19 \%$ of them did not know what to do to cope with these weather-related events.

\subsubsection{Multivariate probit adaptation models}

Heteroscedasticity and multicollinearity are two common problems occurring in econometric analysis with cross-sectional data. Multicollinearity possibly diminishes the accuracy of the estimated parameters. The Variance Inflation Factor (VIF), therefore, needs to be defined and used to unveil the possible multicollinearity among the independent variables (Hallegatte et al., 2016). The means of VIF for all variables in both models are 1.24 (range from 1.02 to 1.50) (less than 10) indicating that multicollinearity is not a problem in these models. Also, we estimated a robust variance estimator based on a variable list of equation-level scores and a covariance matrix to solve the possibilities of heteroscedasticity in these models. The adaptation models' results show that:

1) The Multivariate Probit Model is highly significant (Wald chi2 (65) 157.66; Log likelihood 1039.4316; $\mathrm{P}>$ chi2 0.000 for the flash flood adaptation model (in the case of including farmers' perceptions of flash floods) and Wald chi2 (65) 160.38; Log likelihood

1037.4472; P > chi2 0.000 for the landslide adaptation model (in the case of including farmers' perceptions of flash floods).

2) The Chi-square results of Likelihood ratio test are statistically significant at 1\% (see Table 5) (Likelihood ratio test of rho21 rho31 rho41 rho51 rho32 rho42 rho52 rho43 rho53 rho54

0; chi2 (10) 49.61; Prob > chi2 0.000 for the flash flood adaptation model and the likelihood ratio test of rho21 rho31 rho41 rho51 rho32 rho42 rho52 rho43 rho53 rho54 0 ; chi2 (10) 50.25; Prob > chi2 0.000 for the landslide adaptation model) implying the correlation of the equations in the models. Such results also indicate that the adaptation models used in this study have a strong explanatory power.

The results from the Multivariate Probit Regression models (Table 6 and Table 7) indicate that (1) farmers' perceptions of flash floods, (2) farmers' perceptions of landslides, (3) age of the leader, (4) literacy, (5) ethnicity, (6) household condition, (7) land ownership, (8) farm size, (9) irrigation, (10) extension service connection, (11) market availability, and (12) farm income are the main factors influencing in farmers' adaptation decisions. Some of these variables are significant at different significance levels for one adaptation measure (e.g., (3), (4), (6), (7), (10), (11), or more than one adaptation choices (e.g., (1), (2), (5), (8), (9) (12)), whereas some (e.g., non-farm income, access to credit) are not statistically significant.

3.2.3.1. Farmers' perceptions. Farmers' perceptions of FF\&LS are found to be negative and significant correlated to changing crop patterns but positive and significant relationships in the cases of diversifying crops, soil management and plant protection. As a consequence, farmers who observe increasing trends of FF\&LS are more likely to adapt by means of

Table 5

Covariance of the error terms.

\begin{tabular}{|c|c|c|c|c|c|c|}
\hline \multirow[t]{2}{*}{ Rho } & \multicolumn{3}{|c|}{ Flash flood adaptation model } & \multicolumn{3}{|c|}{ Landslide adaptation model } \\
\hline & Coefficient & Std. Err & $\mathrm{P}>\mathrm{Z}$ & Coefficient & Std. Err & $\mathrm{P}>\mathrm{z}$ \\
\hline rho21 & $0.247^{* * *}$ & 0.078 & 0.002 & $0.246^{* * *}$ & 0.078 & 0.002 \\
\hline rho31 & 0.133 & 0.093 & 0.150 & $0.131^{* *}$ & 0.092 & 0.155 \\
\hline rho41 & $0.295^{* * *}$ & 0.098 & 0.003 & $0.302^{* *}$ & 0.098 & 0.002 \\
\hline rho51 & $0.256^{* * *}$ & 0.080 & 0.001 & $0.267 * * *$ & 0.080 & 0.001 \\
\hline rho32 & 0.082 & 0.092 & 0.373 & 0.084 & 0.092 & 0.362 \\
\hline rho42 & 0.106 & 0.105 & 0.314 & 0.102 & 0.105 & 0.331 \\
\hline rho52 & $0.145^{*}$ & 0.080 & 0.069 & $0.134^{* *}$ & 0.081 & 0.097 \\
\hline rho43 & $0.233^{* *}$ & 0.110 & 0.034 & $0.221^{* *}$ & 0.110 & 0.045 \\
\hline rho53 & 0.097 & 0.089 & 0.274 & 0.095 & 0.089 & 0.287 \\
\hline rho54 & 0.039 & 0.095 & 0.686 & 0.047 & 0.094 & 0.615 \\
\hline
\end{tabular}

Likelihood ratio test of: rho21 rho31 rho41 rho51 rho32 rho42 rho52 rho43 rho53 rho54 0 .

Note: $* * * ; * *$ indicate significance at $10 \%, 5 \%$ and $1 \%$, respectively. 
Table 6

Multivariate probit model of determinants of farmers' adaptation choices (including perception on flash floods).

\begin{tabular}{|c|c|c|c|c|c|c|c|c|c|c|}
\hline \multirow[t]{2}{*}{ Explanatory variables } & \multicolumn{2}{|c|}{ Changing in crop pattern } & \multicolumn{2}{|l|}{ Crop variegation } & \multicolumn{2}{|c|}{ Changing in crop varieties } & \multicolumn{2}{|c|}{$\begin{array}{l}\text { Crop management and } \\
\text { protection (soil and plant) }\end{array}$} & \multicolumn{2}{|l|}{ Others } \\
\hline & Coefficient & $\mathrm{P}>\mathrm{z}$ & Coefficient & $\mathrm{P}>\mathrm{z}$ & Coefficient & $\mathrm{P}>\mathrm{z}$ & Coefficient & $\mathrm{P}>\mathrm{z}$ & Coefficient & $\mathrm{P}>\mathrm{z}$ \\
\hline Flash flood perception & $0.34 * *(0.14)$ & 0.018 & $0.24 *(0.14)$ & 0.078 & $0.04(0.16)$ & 0.821 & $0.83^{* * *(0.19)}$ & 0.000 & $0.08(0.14)$ & 0.564 \\
\hline \multicolumn{11}{|l|}{ Socio-economic characteristics } \\
\hline Age of the leader & $0.10(0.15)$ & 0.516 & $0.39 * * *(0.15)$ & 0.009 & $0.14(0.17)$ & 0.415 & $0.01(0.19)$ & 0.976 & $0.03(0.15)$ & 0.827 \\
\hline Education & $0.16^{* * *}(0.08)$ & 0.047 & $0.01(0.08)$ & 0.852 & $0.02(0.09)$ & 0.861 & $0.10(0.10)$ & 0.354 & $0.06(0.08)$ & 0.458 \\
\hline Ethnicity & $0.35 * *(0.16)$ & 0.036 & $0.20(0.16)$ & 0.233 & $0.42^{* *}(0.19)$ & 0.038 & $0.24(0.21)$ & 0.254 & $0.12(0.17)$ & 0.445 \\
\hline Household condition & $0.30 *(0.17)$ & 0.071 & $0.09(0.16)$ & 0.573 & $0.14(0.18)$ & 0.441 & $0.19(0.21)$ & 0.362 & $0.04(0.16)$ & 0.790 \\
\hline Farm income & $0.13 *(0.07)$ & 0.055 & $0.25^{* * *}(0.07)$ & 0.000 & $0.13 *(0.07)$ & 0.080 & $0.03(0.09)$ & 0.711 & $0.03(0.06)$ & 0.595 \\
\hline Non-farm income & $0.04(0.04)$ & 0.376 & $0.01(0.04)$ & 0.849 & $0.05(0.05)$ & 0.289 & $0.04(0.05)$ & 0.404 & $0.02(0.04)$ & 0.659 \\
\hline Market availability & $0.00(0.03)$ & 0.989 & $0.10^{* * *}(0.03)$ & 0.006 & $0.02(0.03)$ & 0.497 & $0.00(0.03)$ & 0.897 & $0.03(0.03)$ & 0.292 \\
\hline \multicolumn{11}{|l|}{ Farming characteristics } \\
\hline Land ownership & $0.07(0.17)$ & 0.658 & $0.39 * *(0.17)$ & 0.020 & $0.00(0.19)$ & 0.982 & $0.01(0.21)$ & 0.953 & $0.05(0.17)$ & 0.756 \\
\hline Farm size & $0.06 *(0.03)$ & 0.059 & $0.02(0.03)$ & 0.470 & $0.01(0.03)$ & 0.822 & $0.08 *(0.06)$ & 0.085 & $0.03(0.03)$ & 0.344 \\
\hline \multicolumn{11}{|l|}{ Institutional conditions } \\
\hline Irrigation & $0.29 * *(0.14)$ & 0.044 & $0.17(0.14)$ & 0.221 & $0.07(0.16)$ & 0.674 & $0.13(0.18)$ & 0.461 & $0.30 * *(0.14)$ & 0.035 \\
\hline Extension service connection & $0.05(0.15)$ & 0.748 & $0.29 *(0.15)$ & 0.062 & $0.19(0.17)$ & 0.256 & $0.30(0.19)$ & 0.112 & $0.17(0.15)$ & 0.274 \\
\hline Access to credit & $0.13(0.14)$ & 0.378 & $0.12(0.43)$ & 0.414 & $0.15(0.18)$ & 0.335 & $0.27(0.18)$ & 0.135 & $0.13(0.14)$ & 0.364 \\
\hline Constant & $0.87(1.29)$ & 0.500 & $1.98(1.27)$ & 0.119 & $0.58(1.40)$ & 0.683 & $0.25(1.62)$ & 0.878 & $0.75(1.27)$ & 0.553 \\
\hline Model summary & & & & & & /atrho & Coef. & Std.E & $\mathrm{P}>\mathrm{z}$ & \\
\hline Log likelihood $\quad 1043.9229$ & & & & & & /atrho21 & $0.252^{* * *}$ & 0.083 & 0.002 & \\
\hline Wald chi2 (65) 151.78 & & & & & & /atrho31 & 0.133 & 0.094 & 0.155 & \\
\hline \multirow[t]{8}{*}{ Prob $>$ chi2 0.000} & & & & & & /atrho41 & $0.304^{* * *}$ & 0.107 & 0.004 & \\
\hline & & & & & & /atrho51 & $0.262^{* * *}$ & 0.085 & 0.002 & \\
\hline & & & & & & /atrho32 & 0.082 & 0.092 & 0.375 & \\
\hline & & & & & & /atrho42 & 0.106 & 0.106 & 0.317 & \\
\hline & & & & & & /atrho52 & $0.146^{*}$ & 0.081 & 0.073 & \\
\hline & & & & & & /atrho43 & $0.237^{* *}$ & 0.116 & 0.041 & \\
\hline & & & & & & /atrho53 & 0.097 & 0.089 & 0.277 & \\
\hline & & & & & & /atrho54 & 0.039 & 0.096 & 0.686 & \\
\hline
\end{tabular}

Note: The values in the brackets are Standard Errors; ${ }^{*}, * *, * *$ are significant at $10 \%, 5 \%$ and $1 \%$, respectively.

crop variegation, crop management and protection (soil and plant), while, unexpectedly, farmers who do not notice increasing trends are more likely to adapt by changing cropping patterns. The reasoning behind this is that changes in cropping patterns, for example, from cassava to cinnamon or acacia, may not come from the perception of increased likelihood resulting in FF\&LS; but actually derive from the economic benefits of other crops.

Table 7

Multivariate probit model of determinants of farmers' adaptation choices (including perception on landslides).

\begin{tabular}{|c|c|c|c|c|c|c|c|c|c|c|}
\hline \multirow[t]{2}{*}{ Explanatory variables } & \multicolumn{2}{|c|}{ Changing in crop pattern } & \multicolumn{2}{|l|}{ Crop variegation } & \multicolumn{2}{|c|}{ Changing in crop varieties } & \multicolumn{2}{|c|}{$\begin{array}{l}\text { Soil management and plant } \\
\text { protection }\end{array}$} & \multicolumn{2}{|l|}{ Others } \\
\hline & _Coefficient & $\mathrm{P}>\mathrm{z}$ & Coefficient & $\mathrm{P}>\mathrm{z}$ & Coefficient & $\mathrm{P}>\mathrm{z}$ & Coefficient & $\mathrm{P}>\mathrm{z}$ & Coefficient & $\mathrm{P}>\mathrm{z}$ \\
\hline Landslide perception & $0.39 * * *(0.14)$ & 0.006 & $0.27 *(0.14)$ & 0.054 & $0.01(0.16)$ & 0.898 & $0.76^{* * *}(0.21)$ & 0.000 & $0.20(0.14)$ & 0.147 \\
\hline \multicolumn{11}{|l|}{ Socio-economic characteristics } \\
\hline Age of the leader & $0.11(0.15)$ & 0.460 & $0.42^{* * *}(0.15)$ & 0.006 & $0.13(0.17)$ & 0.421 & $0.05(0.18)$ & 0.794 & $0.04(0.15)$ & 0.809 \\
\hline Education & $0.16 *(0.08)$ & 0.050 & $0.01(0.08)$ & 0.855 & $0.02(0.09)$ & 0.868 & $0.08(0.10)$ & 0.354 & $0.05(0.08)$ & 0.470 \\
\hline Ethnicity & $0.34 * *(0.16)$ & 0.043 & $0.19(0.17)$ & 0.237 & $0.41 * *(0.20)$ & 0.040 & $0.22(0.21)$ & 0.299 & $0.17(0.17)$ & 0.358 \\
\hline Household condition & $0.29 *(0.16)$ & 0.080 & $0.07(0.16)$ & 0.599 & $0.13(0.18)$ & 0.438 & $0.16(0.21)$ & 0.394 & $0.02(0.16)$ & 0.881 \\
\hline Farm income & $0.13 *(0.07)$ & 0.066 & $0.27^{* * *}(0.07)$ & 0.000 & $0.14 *(0.07)$ & 0.078 & $0.03(0.09)$ & 0.891 & $0.02(0.07)$ & 0.554 \\
\hline Non-farm income & $0.03(0.04)$ & 0.431 & $0.01(0.04)$ & 0.799 & $0.05(0.05)$ & 0.281 & $0.05(0.05)$ & 0.367 & $0.02(0.04)$ & 0.711 \\
\hline Market availability & $0.00(0.03)$ & 0.947 & $0.10^{* * *}(0.04)$ & 0.004 & $0.03(0.03)$ & 0.504 & $0.01(0.03)$ & 0.733 & $0.04(0.03)$ & 0.241 \\
\hline \multicolumn{11}{|l|}{ Farming characteristics } \\
\hline Land ownership & $0.05(0.17)$ & 0.785 & $0.43^{* *}(0.17)$ & 0.014 & $0.02(0.19)$ & 0.995 & $0.09(0.21)$ & 0.748 & $0.08(0.17)$ & 0.735 \\
\hline Farm size & $0.06 *(0.03)$ & 0.076 & $0.01(0.03)$ & 0.506 & $0.01(0.03)$ & 0.822 & $0.10(0.06)$ & 0.146 & $0.04(0.03)$ & 0.315 \\
\hline \multicolumn{11}{|l|}{ Institutional conditions } \\
\hline Irrigation & $0.30 * *(0.14)$ & 0.042 & $0.18(0.14)$ & 0.240 & $0.06(0.16)$ & 0.671 & $0.11(0.18)$ & 0.451 & $0.30 * *(0.14)$ & 0.041 \\
\hline Extension service connection & $0.05(0.15)$ & 0.744 & $0.29 *(0.15)$ & 0.056 & $0.20(0.17)$ & 0.254 & $0.30 *(0.19)$ & 0.095 & $0.18(0.15)$ & 0.263 \\
\hline Access to credit & $0.11(0.17)$ & 0.434 & $0.12(0.17)$ & 0.348 & $0.15(0.18)$ & 0.336 & $0.20(0.21)$ & 0.209 & $0.12(0.17)$ & 0.407 \\
\hline Constant & $1.24(1.23)$ & 0.456 & $2.66 *(1.24)$ & 0.095 & $0.41(1.35)$ & 0.693 & $0.56(1.53)$ & 0.707 & $0.85(1.21)$ & 0.548 \\
\hline Model summary & & & & & & /atrho & Coef. & Std.E & $\mathrm{P}>\mathrm{Z}$ & \\
\hline Log likelihood $\quad 1042.8049$ & & & & & & /atrho21 & $0.251^{* * *}$ & 0.083 & 0.003 & \\
\hline Wald chi2 (65) 152.86 & & & & & & /atrho31 & $0.132 * *$ & 0.094 & 0.160 & \\
\hline \multirow[t]{8}{*}{ Prob $>$ chi $2 \quad 0.000$} & & & & & & /atrho41 & $0.311^{* *}$ & 0.108 & 0.004 & \\
\hline & & & & & & /atrho51 & $0.273^{* * *}$ & 0.086 & 0.001 & \\
\hline & & & & & & /atrho32 & 0.085 & 0.093 & 0.364 & \\
\hline & & & & & & /atrho42 & 0.102 & 0.106 & 0.335 & \\
\hline & & & & & & /atrho52 & $0.134 * *$ & 0.082 & 0.101 & \\
\hline & & & & & & /atrho43 & $0.225^{*}$ & 0.116 & 0.052 & \\
\hline & & & & & & /atrho53 & 0.095 & 0.090 & 0.290 & \\
\hline & & & & & & /atrho54 & 0.048 & 0.095 & 0.616 & \\
\hline
\end{tabular}

Note: The values in the brackets are Standard Errors; *, **, *** are significant at $10 \%, 5 \%$ and $1 \%$, respectively. 
3.2.3.2. Socio-economic characteristics. The age of the household head which characterizes for farmers' experience has a negative relationship with the likelihood of choosing crop variegation, crop management and protection (soil and plant), and other strategies, as reactions to FF\&LS. Furthermore, the relationship between the age of the household head and adaptation choices is only statistically significant in the case of selecting crop variegation $(\mathrm{P}<0.01)$. The correlation, however, is positive but non-significant with changing crop patterns and changing crop varieties $(P>0.1)$. The result indicates that old household heads are less likely to diversify their farming, change their soil management, plant protection measures, and other strategies. The reason behind this fact is that most old household heads are illiterate and belong to the 'Dao' people; they therefore still cultivate as they carried out in the past, as well as not implement other adaptation responses, such as migration, borrowing money or finding off-farm jobs, etc. The level of education is negatively and significantly $(\mathrm{P}<0.05)$ correlated with farmers' decisions to change cropping patterns. The direction of influence, however, is found to be positive but non-significant with changing crop varieties, soil management and plant protection. It means that less educated farmers tend to change the different types of crop models, as they often cannot decide by themselves which crops are suitable for their household resources (e.g., labor force, land, finance, etc.); they just follow their neighbors in selecting plants.

Ethnicity has mixed effects on farmers' adaptation choices to FF\&LS. It correlated negatively and significantly with changes in cropping patterns and crop varieties at a 5\% significance level. Nevertheless, belonging to an ethnic minority is positively and non-significantly correlated with crop variegation, crop management and protection (soil and plant) $(\mathrm{P}>0.1)$. The negative sign on changing cropping patterns and crop varieties indicates that farmers belonging to the 'Kinh' majority group would choose these adaptation measures as reactions to FF\&LS. On the other hand, minority groups are more likely to adapt by means of crop variegation, crop management and protection (soil and plant). Household condition is negatively and significantly associated with changing cropping patterns $(\mathrm{P}<0.1)$. The correlation of household condition, however, is positive but non-significant with the rest of the adaptation choices, except soil management and plant protection (negative relationship). This result also highlights that household condition only determines farmers' decisions to adopt different cropping pattern strategies. Indeed, wealthier households commonly own more land and financial capital that facilitates their adaptation choices in terms of changing crop models.

Farm income, as hypothesized, has a positive relationship with the likelihood of choosing to change cropping pattern, crop variegation, and changing crop varieties at $10 \%, 1 \%$, and $10 \%$ significance levels, respectively. Wealthier households have the financial resources to invest in new crop varieties, which are usually more expensive than the old varieties; they are also able to use more labor and spend more money diversifying farming. The results from the MVP models, in contrast, indicated that farmers' choices of adaptation strategies could not be explained by non-farm income $(\mathrm{P}>0.1)$. The household survey indicated that between two groups (poor and non-poor households), the poor households have a larger share of non-farm income in the total household income. This is because the poor often have more dependent members and less farmland compared to non-poor households. As a result, they must earn income from non-farming activities, such as collecting and selling cinnamon for traders, and peeling cinnamon bark. In addition, in most of the cases, the poor are less educated than the nonpoor households, they therefore just imitate others in selecting adaptation choices. These may be the main reasons why non-farming income does not affect decision making processes to adapt to FF\&LS.

The market availability is negatively and significantly $(\mathrm{P}<0.05)$ correlated with changes in crop variegation. In other words, the closer the market is, the more favorable it will be for farmers to diversify crops since market access could help farmers buy fertilizer, pesticides, and get more information on agricultural activities.
3.2.3.3. Farming characteristics. As expected, land ownership has a positive correlation with all adaptation measures. However, the relationship is only significant in the case of crop variegation $(P<0.05)$. It indicates the fact that if farmers have full legal rights to their land, they are more likely to diversify their farming system. On other words, to motivate farmer to actively invest in agriculture, government needs to secure their property rights (Kokoye et al., 2013). Farm size is positively and significantly (at 10\% significance level) related to the adoption of soil management and plant protection in the perception model on flash floods. Indeed, farmers with large scale farm land are more likely to have more capital and resources, making it easier for them to adapt to FF\&LS through practices such as applying more protection means for plant like pesticides, fertilizers, as well as adopting mulching technique on their lands or making embankments, weaving stone baskets and planting bamboo trees along the fields. However, farm size unexpectedly negatively determines the adoption of changing cropping patterns in both models. As extracted from the survey data, the visible reason is that households with a large farm size already grew cinnamon or acacia in the past and they are unlikely to change, while those with a small farm size normally planted cassava or maize on the hilly land and now have changed to cinnamon. This result indicates that families with a smaller farm size are likely to adapt to FF\&LS by means of this practice.

3.2.3.4. Institutional conditions. Irrigation has a positive and significant relationship to the likelihood of choosing to change cropping patterns (P $<0.05)$ and other strategies $(\mathrm{P}<0.05)$ as adaptation measures to FF\&LS. It means that irrigated farms are more likely to change cropping pattern or find off-farm jobs, borrow money, or migrate, etc. The positive correlation between irrigation and other strategies can be clarified by the fact that although farmers in the research areas can access irrigation, most of them indicate that irrigation water is not sufficient for their fields, especially in winter (dry season).

Not as hypothesized, contact with extension services has a negative correlation with all adaptation strategies. In addition, the influence is only significant with crop variegation, crop management and protection (soil and plant) at a $10 \%$ significance level. This means that farmers who have access to extension services are more likely to not take adaptation options as reactions to FF\&LS. The negative sign can be clarified by the fact that although extension officials give advice on crop variegation and other farming activities, farmers still make their own decisions. Local farmers think most of the extension officers are young and have less experience in agriculture; hence, farmers would not always follow their guidelines. Finally, the results from the MVP models shows that access to credit does not determine farmers' adaptation choices to FF\&LS. In fact, to support and encourage poor households in fostering agricultural production, the local authority has a policy for the poor to get loans from the 'Social Banks' with a low interest rate (i.e., 6.6\%/year) and with a long loan term (10 years). However, most interviewed households are afraid of borrowing money from the banks for their own business. Instead, they borrowed money from the 'Social Banks' under the support policy of the local government and lent that money to someone else (often to wealthier households or their relatives). In addition, many poor households borrowed money from the government's supporting programs for the poor to spend on other activities, such as buying a motorbike, food, and alcohol, not on cattle or production equipment. As a result, the government's supporting policy was not used for the right purpose and leads to an increasing income gap in the research areas.

\section{Conclusions and policy implications}

Using a data set of a household survey in Van Yen district, Yen Bai province in the Northern Mountainous Regions in Vietnam, this study shed light on how farmers have been adapted to FF\&LS and identified challenges of adaptation. Furthermore, this study also analyzed the key factors that influence farmers' adaptation choices to FF\&LS. The study 
was carried out to help the Vietnamese governments have a better understanding of farmers' behavior and reactions when selecting adaptation strategies to FF\&LS, thereby helping them to develop appropriate supporting policies. This is highly important for this region in Vietnam because this area is considered one of the poorest regions in the country with a majority of the population belonging to minority ethnic groups. They tend to have low levels of education whilst also lack proper clothing, food, clean water, and healthcare services, and live far away from centers of towns. In addition, their main incomes rely on agricultural and forestry activities; hence, they are highly vulnerable to FF\&LS, which frequently occur in the region. Hence, the findings would be good references for policymakers to develop suitable policies to help poor people recover quickly and sustainably from future natural hazard impacts. The results of our case study demonstrate that the MVP model is an appropriate method to explore the complexity of adaptation processes and is replicable to similar physio-geographic areas and smallholder farmers, with the refinement of variables suited to the locality.

The most common adaptation strategies reported include changes in cropping patterns, crop variegation, altering crop varieties, crop management, and protection methods (soil and plant). Technological limitations and financial restrictions, as well as institutional restraints and cognitive barriers should not be disregarded in investigating the adaptive behavior of farmers as they are reported to be amongst the most significant barriers to adaptation. The key drivers of farmers' decisions to implement adaptation strategies are determined by using the MVP model. In the model, the dependent variable is households' adaptation choices that include five adaptation options, and the exogenous variables contain household attributes.

The results of the analysis indicated that the perception of farmers to FF\&LS and households' characteristics, such as belonging to an ethnic minority, the literacy, the household condition, farm income, and market availability, have significant impacts on adaptation strategy preference of farmers. In this regard, our findings call for policies that enhance better knowledge for local farmers through investment in education systems, such as opening free literacy classes, organizing training courses for technology transfers on sustainable land use cultivation and for improving farmers' awareness on sustainable land use.
Information on the weather should be provided to farmers on time. Also, supplying agricultural production inputs with reasonable prices and selling-product-assistance can be considered to be promising solutions in improving people's income, thereby supporting them to adapt to and overcome the adverse impacts of FF\&LS. Upgrading infrastructure, such as roads, should be taken into account to encourage farmers to adapt to FF\&LS.

In addition, this study disclosed that some of the farming characteristics including land ownership and farm size also significantly affect farmers' decision making processes. Since the willingness of farmers to invest in the farming system will be enhanced if they have ownership of their land, creating favorable conditions for people to legalize their land ownership should be considered by policymakers. Institutional factors represented by irrigation system and extension service connection influence farmers' adaptation choices. Feasible directions for future policies are upgrading irrigation systems and improving the quality of extension officers. To do so, the local government should organize training courses (i.e., cultivation techniques, breeding techniques) to enhance the capacity of commune extensionists. Besides, the extension officers need to communicate more often with local farmers to create a good relationship resulting in increasing trust from them. Since the scope of this paper is to examine how policymakers can facilitate the adaptation process at a household level, future analysis needs to properly answer the question over which adaptations are economically viable and most effective at increasing farmers' resilience.

\section{Acknowledgments}

We are very grateful to the Vietnam International Education Cooperation Department and the United Nations University in Bonn, Germany for financing the research. We would like to thank Professor Jakob Rhyner for his supports and guidance and Mr. Harrhy James (United Nations University - Institute for Environment and Human Security) for his insightful comments, Mrs. Trinh Hao and Mrs. Dao Chiem for helping with data collection and also thank all interviewees for participating in the survey.

\section{Appendix}

Table A1

Typical flash floods and landslides in the mountainous provinces of Vietnam

\begin{tabular}{|c|c|c|c|c|}
\hline No. & Type of hazard & Year & Place & Results \\
\hline 1 & Flash flood & July 15, 2000 & Sapa, Lao Cai & 20 dead and 25 injured people \\
\hline 2 & Flash flood & October 03,2000 & $\begin{array}{l}\text { Nam Coong village, Nam Cuoi commune, Sin Ho district, Lai } \\
\text { Chau }\end{array}$ & 39 dead and 18 injured people \\
\hline 3 & Flash flood & August 16, 2002 & Bac Quang and Xin Man districts, Ha Giang & 25 dead and 17 injured people \\
\hline 4 & Flash flood & $\begin{array}{l}\text { September 20, } \\
2002\end{array}$ & Huong Son, Huong Khe, and Vu Quang districts, Ha Tinh & 53 dead and lost, and 111 injured people \\
\hline 5 & Flash flood & 2004 & Du Tien, Du Gia communes, Yen Minh district, Ha Giang & 45 dead people \\
\hline 6 & Landslide & 2004 & Lao Cai & 22 dead and lost, 16 injured people \\
\hline 7 & Flash flood & $\begin{array}{l}\text { September 28, } \\
2005\end{array}$ & Van Chan district, Yen Bai & 50 dead and lost people \\
\hline 8 & $\begin{array}{l}\text { Flood, flash flood, } \\
\text { landslide }\end{array}$ & 2008 & Lao Cai and Yen Bai & 120 dead and lost people \\
\hline 9 & Landslide & 2009 & Pac Nam commune, Bac Kan & 13 dead and five injured people \\
\hline 10 & Flash flood & $9 / 2011$ & Thanh Hoa, Nghe An & Six dead people \\
\hline 11 & Flashflood andlandslide & $\begin{array}{l}\text { September 07, } \\
2012\end{array}$ & Mu Cang Chai district, Yen Bai & Eight dead people \\
\hline 12 & Flash flood & $\begin{array}{l}\text { September 05, } \\
2013\end{array}$ & Ban Khoang commune, Sapa district, Lao Cai & 11 dead and lost, 16 injured people \\
\hline 13 & Flash flood and landslide & $08 / 2017$ & Mu Cang Chai, Yen Bai & $\begin{array}{l}14 \text { dead and missing, nine injured people } \\
29 \text { washed away houses, and } 25 \text { damaged or destroyed } \\
\text { houses }\end{array}$ \\
\hline 14 & Flashflood andlandslide & $09 / 2017$ & Tram Tau, Yen Bai & Two dead and seven injured people \\
\hline 15 & Flash flood and landslide & August 04, 2017 & Muong La district, Son La & $\begin{array}{l}\text { Ten killed, six missing and four injured people. } \\
258 \text { damaged houses }\end{array}$ \\
\hline
\end{tabular}




\section{References}

Adesina, A.A., Baidu-Forson, J., 1995. Farmers perceptions and adoption of new agricultural technology: Evidence from analysis in Burkina Faso. Agric. Econ. 13, $1-9$.

Adger, W.N., Agrawala, S., Mirza, M.M., Conde, C., O’Brien, K., Pulhin, J., Takahashi, K., 2007. Climate Change 2007: Impacts, Adaptation and Vulnerability. Contribution of Working Group II to the Fourth Assessment Report of the Intergovernmental Panel on Climate Change.

Adger, W.N., Barnett, J., Brown, K., Marshall, N., O’Brien, K., 2013. Cultural dimensions of climate change impacts and adaptation. Nat. Clim. Chang. 3, 112-117.

Adger, W.N., Dessai, S., Goulden, M., Hulme, M., Lorenzoni, I., Nelson, D.R., Wreford, A., 2009. Are there social limits to adaptation to climate change? Clim. Change 93, 335-354.

Adger, W.N., Vincent, K., 2005. Uncertainty in adaptive capacity. Cr. Geosci. 337, 399-410.

African Development Bank, Asian Development Bank, Department for International Development-United Kingdom, Commission-Directorate-General for DevelopmentEuropean Commission, Federal Ministry for Economic Cooperation and Development-Germany, Ministry of Foreign Affairs-Development CooperationNetherlands, The World Bank, 2003. Poverty and Climate Change: Reducing the Vulnerability of the Poor through Adaptation.

Agrawal, A., Perrin, N., 2008. Climate Adaptation, Local Institutions and Rural Livelihoods. IFRI Working Paper. W08I-6.

Anim, F.D.K., 1999. A note on the adoption of soil conservation measures in the northern province of South Africa. J. Agric. Econ. 50, 336-345.

Anley, Y., Bogale, A., Haile-Gabriel, A., 2006. Adoption decision and use intensity of soil and water conservation measures by smallholder subsistence farmers in Dedo district, Western Ethiopia. Land Degrad. Dev. 18, 289-302.

Antwi-agyei, P., Dougill, A.J., Lindsay, C., 2013. Barriers to Climate Change Adaptation in Sub- Saharan Africa: Evidence from Northeast Ghana \& Systematic Literature Review. Centre for Climate Change Economics and Policy Working Paper, p. 154.

Bayard, B., Jolly, C.M., Shannon, D.A., 2007. The economics of adoption and management of alley cropping in Haiti. J. Environ. Manag. 84, 62-70.

Bekele, W., Drake, L., 2003. Soil and water conservation decision behavior of subsistence farmers in the Eastern highlands of Ethiopia: a case study of the hunde-Lafto area. Ecol. Econ. 46, 437-451.

Below, T.B., Mutabazi, K.D., Kirschke, D., Franke, C., Sieber, S., Siebert, R., Tscherning, K., 2012. Can farmers' adaptation to climate change be explained by socio-economic household-level variables? Glob. Environ. Chang. 22, 223-235.

Biesbroek, G.R., Klostermann, J.E.M., Termeer, C.J.A.M., Kabat, P., 2013. On the nature of barriers to climate change adaptation. Reg. Environ. Chang. 13, 1119-1129.

Bradshaw, B., Dolan, H., Smit, B., 2004. Farm-level adaptation to climatic variability and change: crop diversification in the Canadian prairies. Clim. Change 67, 119-141.

Bryan, E., Deressa, T.T., Gbetibouo, G.A., Ringler, C., 2009. Adaptation to climate change in Ethiopia and South Africa: options and constraints. Environ. Sci. Policy 12, 413-426.

Burton, M., Rigby, D., Young, T., 1999. Analysis of the determinants of adoption of organic horticultural techniques in the UK. J. Agric. Econ. 50, 47-63.

CARE, 2013. Climate Vulnerability and Capacity of Ethnic Minorities in the Northern Mountainous Region of Viet Nam.

Chaudhry, P., Ruysschaert, G., 2008. Human Development Report 2007/2008: Fighting Climate Change: Human Solidarity in a Divided World - Climate Change and Human Development in Viet Nam.

Daberkow, S.G., McBride, W.D., 2003. Farm and operator characteristics affecting the awareness and adoption of precision agriculture technologies in the US. Precis Agric. 4, 163-177.

Davies, S., 1996. Adaptabel Livelihoods: Coping with Food Insecurity in the Malian Sahel. Macmillan Press LTD.

Deressa, T., 2009. Determinants of farmers' choice of adaptation methods to climate change in the nile basin of Ethiopia. Glob. Environ. Chang. 19, 248-255.

Deressa, T., Hassan, R.M., Ringler, C., 2009. Assessing Household Vulnerability to Climate Change: the Case of Farmers in the Nile Basin of Ethiopia. IFPRI Discussion Paper, p. 935.

Dhakal, B., 2016. Can we get better information by any alternative to conventional statistical approaches for analysing land allocation decision problems? A case study on lowland rice varieties. Land Use Policy 54, 522-533.

Dolisca, F., Carter, D.R., McDaniel, J.M., Shannon, D.A., Jolly, C.M., 2006. Factors influencing farmers' participation in forestry management programs: A case study from Haiti. For. Ecol. Manag. 236, 324-331.

Featherstone, A.M., Goodwin, B.K., 1993. Factors influencing a Farmer's decision to invest in long-term conservation improvements. Land Econ. 69, 67-81.

Feder, G., Just, R.E., Zilberman, D., 1985. Adoption of agricultural innovations in developing Countries: A survey. Econ. Dev. Cult. Change 33, 255-298.

Feleke, F.B., Berhe, M., Gebru, G., Hoag, D., 2016. Determinants of adaptation choices to climate change by sheep and goat farmers in Northern Ethiopia: the case of Southern and Central Tigray, Ethiopia. SpringerPlus 5, 1692.

Gbetibouo, G.A., 2009. Understanding Farmers' Perceptions and Adaptations to Climate Change and Variability: the Case of the Limpopo Basin. IFPRI Discussion Paper, South Africa, p. 849.

Golob, T.F., Regan, A.C., 2002. Trucking industry adoption of information technology: A multivariate discrete choice model. Transport. Res. C-Emer. 10, 205-228.
Gould, B.W., Saupe, W.E., Klemme, R.M., 1989. Conservation tillage: The role of farm and operator characteristics and the perception of soil erosion. Land Econ. 65, $167-182$.

Grothmann, T., Patt, A., 2005. Adaptive capacity and human cognition: The process of individual adaptation to climate change. Glob. Environ. Chang. 15, 199-213.

GSO, 2017. Statistical Yearbook of Vietnam.

Hallegatte, S., Bangalore, M., Bonzanigo, L., Fay, M., Kane, T., Narloch, U., VogtSchilb, A., 2016. Shock Waves: Managing the Impacts of Climate Change on Poverty. The World Bank Group.

IPCC, 2001. Climate Change 2001: Impacts, Adaptation, and Vulnerability. Contribution of Working Group II to the Third Assessment Report of the IPCC.

IPCC, 2014. Climate Change 2014: Impacts, Adaptation, and Vulnerability. Part A: Global and Sectoral Aspects. Contribution of Working Group II to the Fifth Assessment Report of the IPCC.

Jensen, R., 1982. Adoption and diffusion of an innovation of uncertain profitability. J. Econ. Theory 193, 182-193.

Jonkman, S.N., 2005. Global perspectives on loss of human life caused by floods. Nat. Hazards 34, 151-175.

Just, B.R.E., Zilberman, D., 1983. Stochastic structure, farm size and technology adoption in developing agriculture. Oxf. Econ. Pap. 35, 307-328.

Kam, S.P., Badjeck, M., Teh, L., Teh, L., Tran, N., 2012. Autonomous Adaptation to Climate Change by Shrimp and Catfish Farmers in Vietnam's Mekong River Delta Working Paper, pp. 2012-2024.

Kokoye, S.E.H., Tovignan, S.D., Yabi, J.A., Yegbemey, R.N., 2013. Econometric modeling of farm household land allocation in the municipality of Banikoara in Northern Benin. Land Use Policy 34, 72-79.

Koundouri, P., Nauges, C., Tzouvelekas, V., 2006. Technology adoption under production uncertainty: theory and application. Am. J. Agric. Econ. 88, 657-670.

Kurukulasuriya, P., Mendelsohn, R., 2006. Crop selection: adapting to climate change in Africa. CEEPA Discuss. Pap. 26, 1-29.

Lapar, M.L., Pandey, S., 1999. Adoption of soil conservation: The case of the Philippine uplands. Agric. Econ. 21, 241-256.

Le Dang, H., Li, E., Bruwer, J., Nuberg, I., 2014. Farmers' perceptions of climate variability and barriers to adaptation: Lessons learned from an exploratory study in Vietnam. Mitig. Adapt. Strategies Glob. Change 19, 531-548.

Lin, C.J., Jensen, K.L., Yen, S.T., 2005. Awareness of foodborne pathogens among US consumers. Food Qual. Prefer. 16, 401-412.

Maddison, D., 2006. The Perception of and Adaptation to Climate Change in Africa. Centre for Environmental Economics and Policy in Africa. Policy Research Working Paper, p. 4308.

Marconi, M., Marincioni, F., Tran, V.G.P., 2011. Strengthening Capacities to Enhance Coordinated and Integrated Disaster Risk Reduction Actions and Adaptation to Climate Change in Agriculture in the Northern Mountain Regions of Vietnam: Hazard, Vulnerability and Risk Mapping in Lao Cai, Yen Bai and Phu Tho.

McElwee, P.D., Tuyen, N.P., Le, T.V.H., Vu, T.D.H., Nguyen, V.B., Le, Q.T., Adutt, G., 2010. Economics Adaptation to Climate Change: the Social Dimensions of Adaptation to Climate Change in Vietnam. The World Bank Discussion Paper, p. 12.

McKinley, J., Adaro, C., Pede, V.O., Rutsaert, P., Setiyono, T., Tran, C.T., Wassmann, R., 2016. Gender differences in climate change perception and adaptation strategies: the case of three provinces in Vietnam's Mekong river delta, CCAFS report. CGIAR Research Program on Climate Change, Agriculture and Food Security (CCAFS).

MONRE, 2009. Climate Change, Sea Level Rise Scenarios for Vietnam.

MONRE, 2017. National Disaster Risk in Viet Nam in the Period 2006-2016 and Forecasting and Warning System. $11^{\text {th }}$ Emergency Preparedness Working Group Meeting.

Moser, S.C., Ekstrom, J.A., 2010. A framework to diagnose barriers to climate change adaptation. Proc. Natl. Acad. Sci. U.S.A. 107, 22026-22031.

Nhemachena, C., Hassan, R., 2008. Micro-level Analysis of Farmers' Adaptation to Climate Change in Southern Africa. IFPRI Discussion Paper, p. 714.

Norris, P.E., Batie, S.S., 1987. Virginia Farmers Soil Conservation Decisions: An Application of Tobit Analysis. South. J. Agric. Econ. 79-90.

Nyangena, W., 2008. Social determinants of soil and water conservation in rural Kenya. Environ. Dev. Sustain. 10, 745-767.

Okoye, C.U., 1998. Comparative analysis of factors in the adoption of traditional and recommended soil erosion control practices in Nigeria. Soil. Till. Res. 45, 251-263.

Pham, K.N., 2011. Social Capital and Private Adaptation to Climate Change: Evidence from the Mekong River Delta in Vietnam.

Pham, T.H., Le, D.T., Nguyen, V.C., 2010. Poverty of the Ethnic Minorities in Vietnam: Situation and Challenges from the Poorest Communes. MPRA (Munich Personal RePEc Archive) Paper, p. 50372.

Piya, L., Maharjan, K.L., Joshi, N.P., 2013. Determinants of adaptation practices to climate change by Chepang households in the rural Mid-Hills of Nepal. Reg. Environ. Chang. 13, 437-447.

Saha, A., Love, H.A., Schwart, R., 1994. Adoption of emerging technologies under output uncertainty. Am. J. Agric. Econ. 76, 836-846.

Salvati, P., Petrucci, O., Rossi, M., Bianchi, C., Pasqua, A.A., Guzzetti, F., 2018. Gender, age and circumstances analysis of flood and landslide fatalities in Italy. Sci. Total Environ. 610-611, 867-879.

Shiferaw, B., Holden, S.T., 2006. Resource degradation and adoption of land conservation technologies by smallholders in the Ethiopian highlands: A case study in Andit. North Shewa. Agr. Econ. 18, 1-29. 
Smit, B., Wandel, J., 2006. Adaptation, adaptive capacity and vulnerability. Glob. Environ. Chang. 16, 282-292.

Thacher, T., Lee, D.R., Schelhas, J.W., 1996. Farmer participation in reforestation incentive programs in Costa Rica. Agrofor. Syst. 35, 269-289.

Trinh, T.Q., Ranola Jr., Roberto F., Camacho, Leni D., Simelton, Elisabeth, 2018. Determinants of farmers' adaptation to climate change in agricultural production in the central region of Vietnam. Land Use Policy 70, 224-231.

Tse, Y.K., 2006. A diagnostic test for the multinomial logit model. J. Bus. Econ. Stat. 5, 283-286.

UN-VietNam, 2014. Migration, Resettlement and Climate Change in Viet Nam: Reducing Exposure and Vulnerabilities to Climatic Extremes and Stresses through Spontaneous and Guided Migration.

Waibel, H., Pahlisch, T.H., Volker, M., 2018. Farmers' perceptions of and adaptations to climate change in Southeast Asia: The case study from Thailand and Vietnam. Nat. Res. Man. 52, 137-160.
Wooldridge, J.M., 2008. Econometric Analysis of Cross Section and Panel Data. The MIT Press Cambridge, Massachusetts London, England.

World Bank, 2011. Climate Risk and Adaptation Country Profile. Vietnam: Vulnerability, Risk Reduction and Adaptation to Climate Change.

World Bank, 2012. Vietnam Poverty Assessment: Well Begun, Not yet Done: Vietnam's Remarkable Progress on Poverty Reduction and the Emerging Challenges.

Yegbemey, R.N., Yabi, J.A., Tovignan, S.D., Gantoli, G., Haroll Kokoye, S.E., 2013. Farmers' decisions to adapt to climate change under various property rights: a case study of maize farming in northern Benin (West Africa). Land Use Policy 34 168-175.

Zhang, D., Flick, W.A., 2001. Sticks, carrots, and reforestation investment. Land Econ. 77, 443-456. 